\title{
RESPONDING TO GENOCIDE IN RWANDA: LOCAL KNOWLEDGE AND COUNTER-STORIES
}

\author{
DAVID Denborough AND Cheryl White \\ (in collaboration with Hodali Irakoze Pierre Claver, Jill \\ Freedman and Gene Combs)
}

From April to July 1994, a genocide perpetrated against the Tutsi people in Rwanda claimed over one million human lives. It is now 18 years later and the survivors of the genocide continue to face profound hardships in relation to housing, health, education, extreme poverty, and security. The vast majority of survivors still live in great suffering and with nightmares of the traumatic past. The genocide aimed to eliminate the Tutsi, and this entailed the elimination of families - fathers, mothers, and children. After the genocide, the survivors regrouped on the basis of kinship, friendship, or just kind-heartedness of spirit. Associations fighting for victims' rights are constantly committed. Ibuka is a national organisation in Rwanda that represents survivor associations throughout the country (see Kaboyi, 2007).

Six years ago, the authors first met with Kaboyi Benoit, at that time the executive secretary of Ibuka. After initial introductions, and in response to our 'down under' accents, Benoit said 'Ah, Australia...there's a country that knows all about genocide.'

This recognition and our conversation following signalled the beginning of a partnership between Ibuka and Dulwich Centre Foundation International, an Australian-based organisation which responds to groups and communities who have experienced significant hardship. Much of our work involves cultural partnerships and building the capacity of local workers through the use of narrative practices to elicit and richly describe local knowledge. Within any community experiencing social suffering, community members will be 
responding to these difficulties: they will take whatever action is possible - in their own ways, based on particular skills and local knowledge-to try to address the effects of the hardships on their lives and of those they love. These initiatives may not currently be widely recognised, and they may not in themselves be enough to overcome all that is presently facing their community. But these initiatives are highly significant. They make it possible for community members to identify these initiatives, to describe them so that the skills and local knowledge implicit within them become more visible to themselves and to others, and to trace the social histories of these skills and knowledge so that the ways these are linked to local culture and tradition are understood. These initiatives can be strengthened in ways that make further action possible.

After our initial meeting, Kaboyi Benoit expressed his willingness for meetings to be held between Ibuka trauma counsellors/assistant lawyers and a range of international narrative therapists and community workers. Four such meetings have taken place. The partnership has also resulted in an interview with Kaboyi Benoit, 2007, and two publications: Strengthening Resistance: The use of narrative practices in working with genocide survivors (Denborough, Freedman and White, 2008) and Working with Memory in the Shadow of Genocide: The narrative practices of Ibuka trauma counsellors (Denborough, 2010).

This essay conveys some of the intricate, local knowledge of Ibuka counsellors/survivors in relation to:

- the continuing effects of the genocide;

- what sustains survivors as they live in the shadow of genocide;

- ways in which survivors negotiate 'living side by side' with those who have done them great harm; and 
- ways of responding when survivors cannot locate the bodies of loved ones.

Significantly, we also explore how narrative practices have been used to facilitate the excavation, documentation and circulation of this local knowledge and what this is making possible.

\section{(i) Local knowledge in relation to the continuing effects of genocide}

One of the first realms of local knowledge that was articulated by the Ibuka survivors/counsellors relates to the continuing effects of the genocide. The following collective narrative document was constructed from the rescued spoken words of participants:

The effects of the genocide that took place in Rwanda in 1994 are not over. Many people still live with the effects of the extreme violence, killings, and degradation that took place here during those one hundred days. So many of our loved ones are no longer with us. We are a group of trauma counsellors and assistant lawyers who work for Ibuka - the national survivors' association in Rwanda. We work around our country to support and assist survivors of the genocide.

The people with whom we meet are often dealing with many different effects of the genocide. They may be having nightmares and be unable to sleep. They may experience powerful feelings of despair and hopelessness. Often they have profound sorrow, fears, or anger. Some may not know whether they wish to live or to die, which means they are negotiating with death. Some survivors experience severe headaches. Others have difficulty swallowing and may feel as if they are choking. Many survivors are very isolated, very alone. When you have lost so many people it is sometimes very difficult to have relationships with others again. Some women who were raped during the genocide are now HIVpositive and are living with the consequences of this.

And then there are the problems of memory. Some survivors have lost their memories and therefore have lost aspects of their past. Others have painful memories that return again 
and again. What is more, some survivors may feel guilty for being alive. The genocide has made them doubt that they have a right to live. These are all effects that the genocide is still having on survivors.

There are also circumstances in the present that are very difficult to deal with. Some survivors are living in the same villages as those who killed their relations and family members. There is hostility and hatred that they have to deal with every day. Many survivors are also living in severe poverty. These are continuing obstacles to dealing with the effects of the genocide.

Children and young people are also living with the effects of the killings. Even if they were not born at the time of the genocide, they are living with the effects that these events had on their parents and relatives.

These are just some of the effects of the genocide that people are living with. These are the effects which we are responding to in our work (Denborough, Freedman and White, 2008, 1-2).

The retelling of this document, which took place in a ceremonial way within our first meeting, was experienced as powerfully resonant by Ibuka counsellors who stated:

This is an important document. We would be honoured if you could send this to others, to your friends in other countries who are also dealing with difficulties. And to the United Nations!

Listening to this collective retelling enabled the Ibuka counsellors to place their initiatives, their efforts and anguishes, into a broader storyline. Such retelling enables a particular distance from the immediacy of one's own experiences, which in turn provides the possibility for renewed compassion for one's own life and the life of one's community. And through interweaving the words of many, a sense of 'communitas' (Turner, 1969, 1979) is generated. The generation and performance of this particular document can be seen as a form of 'communalisation of suffering' 
(Humphrey cited in Westoby, 2009, 88) to accompany the many other collective rituals of remembrance that are held in Rwanda during the 100 days of memory each year. ${ }^{1}$

The effects of genocide are informed by an 'externalising' ethic (White and Epston, 1990; White, 1997). Narrative practice refuses to locate problems within people-instead, it insists that problems are placed back into the social contexts in which they were produced. And so, rather than survivors being described by professionals as 'suicidal', the description reads: 'Some may not know whether they wish to live or to die, which means they are negotiating with death.' Similarly, rather than experiences of 'survivor guilt' being located internally, the description reads: 'What is more, some survivors may feel guilty for being alive. The genocide has made them doubt that they have a right to live.'

As Kaboyi Benoit explains, the message of this document about the current effects of genocide has a wider significance:

During the genocide, the wider world largely turned its backs on us and we know that many people regret this. Perhaps if the wider world reads this document, if they realise that the effects of the genocide are continuing, they will also realise that it is possible for them to take action now to assist us in our work with survivors (personal communication, 15 November, 2007).

(ii) Local knowledge in relation to 'living in the shadow of genocide'

Narrative practice is vitally interested in what has been referred to as 'double-listening' (White, 2004) and the

${ }^{1}$ Each year in Rwanda, 100 days are set aside as a memorial period to acknowledge the 100 days of the killings that took place in 1994. Throughout this period, memorial and remembrance events are held throughout the country. To read about the ways in which Ibuka workers construct 'double-storied' remembrance events, see Working with Memory in the Shadow of Genocide (Denborough, 2010). 
development of 'double-storied testimonies' (Denborough, 2006). It is both relevant to elicit and richly acknowledge the effects of the externalised problem-in this case the continuing effects of the genocide - and to unearth the diverse responses, initiatives and skills of survival that survivors/ counsellors are enacting as they live in the shadow of genocide. A particular method was used to ensure a 'rich description' of these survival skills. ${ }^{2}$

The words and stories of Ibuka counsellors were collated into a collective document entitled: 'Living in the shadow of genocide: how we respond to hard times-stories of sustenance from the workers of Ibuka.'

Included here are just five of the 15 themes that comprise

2 Participants were asked to break into groups of three and consider the following questions:

- Please describe something (a particular value, belief, skill or knowledge) that gets you or your family/friends through hard times.

-Share a story of a time when this special value, belief, skill or knowledge has made a difference to you or to others.

-Please speak of the social history of this skill, value or belief. How did you learn this? Who did you learn it from? Or who did you learn it with?

-Is this linked in some way to any particular groups, family, communities or cultural histories of which you are a part?

Participants were asked to consider these questions in groups of three. Each person took turns to respond to the questions, to ask the questions, and to take notes of the responses. Participants were invited to try to elicit particular details, to pay attention to metaphors and word images, and to take note of rich descriptions including ways in which people included sensory descriptions in their responses. All the responses from participants were then gathered and woven into a collective document. Patrick Iregura played a critical translating role throughout this process. 
this document:

\section{-Listening and learning from the lives of others}

Listening to the stories of others helps some of us get through. In our work, we hear stories from people who are carrying on their lives even though so much has happened to them. I recall listening carefully to one widow in particular who is continuing to live and care for her three children. This idea of listening to people carefully came from my mother. She would always listen to me during my childhood. Listening is also a part of Rwandan culture. We have seen people overcome very difficult problems. Their lives serve as an example that problems can be solved, that many things are possible.

\section{-Tears and then talking}

Some of us are sustained by our tears. To cry, to shed tears, to allow them to fall, can make a difference. For some of us, there is a tranquillity that comes after tears that can allow us to sleep. After sleep, we may then take time to talk to someone. One person described that, 'When I am sleeping, the tears that I have cried give me strength. When I sleep after I have cried, I am tranquil. There is no noise, only calmness. This way of sustenance came from my mother. Whenever my mother was in pain, she used to allow herself to cry. After her tears had fallen she would go and talk to her friends.' Some of us are sustained by tears and then talking.

\section{-New ways of carrying on traditions}

There is a tradition in Rwanda that we respect the parents in our families. We see them as capable of everything, and we trust the answers that they give to us. We rely on their advice. Many of us lost our parents in the genocide and so we have to find ways to continue to stay in touch with their advice. One person said, 'When I have hard times, I write. I imagine that it is my father writing to me, giving me answers. I think these answers are the appropriate ones.' Some of us are finding new ways to carry on our tradition of seeking and respecting advice from our parents. 


\section{-Recalling good memories}

Sometimes good memories protect us. During the war, I was fighting on the front when we ran short of ammunition. We were left with no options. We had nowhere to flee and no supplies. It was at this time that I started to think about how my life was going to end. I remembered then that my father used to say that a true man, a real man, is strengthened by the good moments in his life. And then good memories started to come into my mind. I started to think about my girlfriend who I had left in my village. And I remembered how my father loved me so much. At this point, I stood up and told the rest of the company to pull back. We did this and even though it was through bullets and fire we made it. We found safety. Sometimes good memories protect us. And some of us learnt this from our families.

\section{-Realising I am not the only one to have that kind of pain}

The experiences we have had are so extreme that we may think we are the only ones to know this kind of pain: the pain of torture, the pain of seeing your loved ones murdered, the pain of surviving when others were killed in your place. Now, though, we realise that others also know this kind of pain. When an old woman came to see me in counselling she told me a terrible story. At first I was not sure what to do, but then an idea came into my head. I decided to talk to some other old ladies and hear what happened to them. I realised that that old woman who came to see me wasn't the only one to have that kind of pain. Once we realise this, it is then possible for people to talk together. Now, whenever I have a problem, I talk to someone else to see if I am the only one to have that kind of problem. That's how some of us sustain ourselves. We consider not only what we went through, but also what others have endured.

Other themes among the 15 included: 'Acts of prayer - talking with a strength beyond us', 'music and song', 'finding ways to rest', 'making family', 'bringing emotions and opinions out into the world', 'respecting ancestors', 'sports', 'keeping a distance', 'hard work for ourselves and for our loved ones', 
and 'turning to friends and seeking company'.

The generation and retelling of this document was partly a response to the Ibuka counsellors' descriptions of the 'problems of memory': 'Some survivors have lost their memories and therefore have lost aspects of their past. Others have painful memories that return again and again.' Eliciting local knowledge about what sustains survivors in the present, carefully excavating the social histories of the values and skills implicit in these practices of sustenance, and then documenting/representing/circulating this knowledge, involves travelling down alternative pathways to memory and to history. When within the document survivors speak in terms of 'this way of sustenance came from my mother' or 'some of us learnt this from our families', they are linking their actions in the present to the legacies of lost loved ones. They are travelling through time in ways that contribute to sustenance. In contexts where relationships with memory are fraught, this process seeks to work both individually and collectively to develop an alternative 'rich textual heritage' (Lowenthal in Wertsch, 2002, 62) and to provide a more 'usable past' (Wertsch, 2002, 45).

Along the way, this process of excavation, documentation and retelling can contribute to the development of a particular 'community of memory' (Bellah, Madsen, Sullivan, Swidler and Tipton, 1985, 105). Just as the earlier document represented the 'communalisation of suffering', this form of documentation represents shared memories of sustenance. As the Ibuka counsellors described:

This document can be used to advocate for survivors. And we can also use it in our work with survivors. It can assist us to notice the many different forms of resistance that we as survivors are demonstrating.

The 15 themes of the document also act as the seeds of 'counter-stories' (Nelson, 2001):

...counter-stories aim to free not only individuals but the entire group whose identity is damaged by an oppressive 
master narrative' (183). As Nelson (2001) describes, many counter-stories start small-'like a seed in the crack of a sidewalk, but they are capable of displacing surprising chunks of concrete as they grow' (169). The Ibuka counsellors reported that when they shared the document 'Living in the shadow of genocide...' with others during the 100 days of commemoration that take place each year in Rwanda, this sharing contributed to a decrease in the number of survivor crises.

Further, in their daily work, Ibuka counsellors elicit and co-author counter-stories with individuals and groups in highly skilful ways. They do so by using the following principles:

- Bridging the gap: listening for what survivors have endured and the effects of this;

- Bringing the current effects of the genocide out of the shadows;

- Listening for what has survived and how this has survived;

-Tracing histories of what is important to survivors;

- Making it possible for survivors to see how they are carrying forth the legacies of loved ones who have died;

- Acknowledging special skills of survival;

- Never separating healing from justice;

- Enabling survivors to make contributions to others; and

- Sharing memory: finding ways to ensure that survivors are not left alone with memories that are too hard to bear. ${ }^{3}$

${ }^{3}$ For more detailed descriptions of these principles, and for examples of the work of Ibuka counsellors, see Denborough (2010), Working with Memory in the Shadow of Genocide: The narrative practices of Ibuka counsellors, 8-9. 
(iii) Local knowledge in relation to 'living side by side with those who have done us harm'

In November 2010, Ibuka counsellors spoke of the dilemma of how they can assist survivors in 'living side by side' with those who have done their families great harm. Many survivors of the genocide in Rwanda continue to live in the same villages as those who participated in the killings. Some women also live alongside those who sexually assaulted them. Eighteen years on from the genocide, even in situations in which the perpetrators served prison sentences, many have now been released and Ibuka workers report that some survivors currently live with continuing threats and hostility.

As the counsellors are survivors, it was decided to elicit and describe the skills, practices, philosophies and local knowledge that they themselves are using to respond to the complexities of 'living side by side'. In small groups, they were invited to name their particular responses, to share stories about these, and to trace the social histories or the source of their particular approaches. Individual responses were then woven into the following collective document:

\section{Living side by side with those who have done us harm}

We are survivors and we are also counsellors. So we bring together our experiences as survivors and our experiences as professionals. These are like two different worlds. When we bring these two worlds together-the world of our experiences, and the world of the trainings that we attendwe create new understandings. As we go, we even have to coin new words.

This document describes some of the skills that we as survivors use here in Rwanda as we have to live side by side with those who perpetrated the killings during the genocide.

This is very difficult. Some survivors are living in the same villages as those who killed their relations and family members. These survivors are sometimes living with continuing threats and violence to try to intimidate them not to speak of the past, not to seek justice. And when survivors 
do speak up, when they do seek justice they must deal with people's reactions. There is hostility and hatred that they have to deal with every day. Now that the Gacaca ${ }^{4}$ process is over, witnesses who have testified are sometimes harassed and persecuted.

So how do we as survivors respond? How do we go about living side by side here in Rwanda? There are many different ways. We do not all do the same thing. We have documented here some of the skills we use. We hope this document may be of assistance to others.

\section{To keep a distance}

Some of us try to keep a distance from those who caused our families harm. At first, straight after the genocide, many survivors moved to a different part of the country-especially from rural areas into the towns. Now, with the unity and reconciliation policies of the government this is not possible. But even if we cannot move, if we are forced to live in the same community, then we might still try to keep a distance

${ }^{4}$ Gacaca is a traditional form of dispute resolution in Rwanda that was used to bring perpetrators of the genocide to some form of community justice. As Rakiya Omaar (2007) explains: '[After the genocide] it was very apparent from the outset, that given the unprecedented level of Gacaca, popular participation in the killings in Rwanda, unprecedented in world history in terms of the percentages of people from the very old to the very young who participated, that it was never going to be possible to achieve justice using the formal western justice system. If there was even an attempt to put the majority of detainees through the courts, let alone all those yet to be arrested, then they would die of old age in the prisons because the entire system would be overwhelmed. The formal court system was simply not a viable option (54).' The community courts were therefore established as a method of transitional justice, designed to promote three imperatives (which were sometimes competing and conflicting): justice, truth, and reconciliation. For more information see Omaar (2007). 
because this lessens the chance of a direct clash. For me, if I realise that something is going to bring me into direct contact with the person who harmed my family, I try to avoid him. I do this so that I will not lose momentum. I know that seeing him will take me back to zero. It will cost me all the efforts I have made to rebuild my life. I don't want to be stopped in my path towards a better future. I don't want to lose momentum in reconstructing my life, so I try to keep a distance. Sometimes we have to keep this distance only in our minds. Some of us act as if the perpetrators are not actually living here. I relate as if they are non-existent. This is my way of keeping a distance. I try to convince myself that they are not here. I don't give them any space in my mind. I erase them from my mind. Some of us still find ways to keep a distance.

\section{Acts of prayer}

Others of us turn to prayer. My prayers strengthen me to live alongside the perpetrators. God has often understood me in ways that provide strength. And when I feel there is no justice then I remember that it is God who judges. This gives me strength to live side by side during this lifetime. Some of us also join prayer groups. Being part of something bigger can bring a sense of peace. When I am joined with others, and feel a sense of peace, it helps me to consider forgiveness. Before the genocide almost all families were very religious. For many survivors, acts of prayer are not only a way of finding a refuge but also a way of honouring what our parents and relatives respected. Some of us turn to prayer in order to live side by side.

\section{To rebuild a certain bond}

For others, when we realise there is no way we can change this situation, we accept it and then try to be diplomatic and friendly with those who are a threat. If we are living in the same neighbourhood, we find ways to rebuild a certain bond. Often we have to make the first move. This might involve socialising or taking part in community events. If they have a family member in hospital then we might show our concern and care for that person. Some of us act as engaged citizens to try to rebuild the bonds in this country. 


\section{To focus on the positive aspects of cohabitation}

Some of us try to not only remember the terrible history here but also to focus on the positive aspects of cohabitation. I look for any service I can offer. And I look for any form of integrity in the families that have caused my family harm. Even with people who have done the worst, there is always something you can build on. It is easy to find hate, but I have found that it is also possible to find one aspect from which to build a new relationship. Some of us try to focus on the positive aspects of living side by side.

\section{To speak in a general way}

Sometimes we have to express our frustrations and we have learned to do this in particular ways. During public presentations of meetings, we speak generally. If the person standing next to me is from a perpetrator family, then I will not curse his family. I will not express my outrage directly at him. I will instead curse in a general way. I will express my frustration at the whole general group of perpetrators and the harm that they have done. Some of us have learnt special skills in how we express our frustrations.

\section{Deep breathing}

The act of breathing deeply is significant to me. As soon as I come in contact with a person who will raise all the memories and who could break my heart, I step aside and I breathe deeply. In order to appease the negative emotions rising within me, in order to appease the flashbacks, I deeply breathe.

\section{Times when survivors have a voice}

There are other times and places where survivors have a voice. During the commemoration period, if a survivor has a trauma crisis then this is an opportunity to get everything off their chest, to give voice to all their frustrations. During such a crisis, survivors can say whatever it is necessary to say. Sometimes we even find people expressing their emotions by doing or recalling what they had endured during the 
genocide. During the commemoration period there are also events that give voice to all that we experience. These moments and these commemoration events are important. They contribute to making it possible for us to live side by side in this land.

\section{Offering forgiveness for peace}

Sometimes, particularly in the country, in small villages, when survivors notice how delicate our position is, when we are surrounded by the families of perpetrators, we may go to these families and offer them forgiveness even before they have asked for it. Life in the village depends on harmony between people so sometimes we offer this forgiveness for peace.

\section{Seeking justice}

In order to live side by side, it has been important for many of us to seek justice. Despite the difficulties and disappointments many survivors have experienced with Gacaca, trying to find the truth of what happened in the genocide, is also about living side by side.

\section{Families}

Sometimes, living side by side happens within families. In families where there was intermarriage and one parent has been killed by the other side of the family, what is to happen with the children? They are sometimes raised by the side of the perpetrator because no one wants them to be completely isolated from their family. In these situations, for the children, even though the family has taken part in the massacre, we must find ways to integrate these families, to live side by side.

\section{Responsibility}

One of the things that can help us to live side by side is when only one member of a family was the perpetrator but the others were innocent or did not take part in the killings. When we know this, when we remember this, it can help. Even though the family's reputation is tarnished, we acknowledge that the responsibility was only with the people who committed the acts. When we know this it can become 
possible to rebuild relationships with that family.

\section{Sticking together}

When we are lucky enough to have a few neighbours who are also survivors this makes the difference. If there are three of four families in the same neighbourhood then we try to help one another. We gather every once and a while and discuss the challenges we are facing. Some of us have also sought out training so we can assist others. Because we can relate to each other's difficulties, we stick together and this can make all the difference.

\section{Working hard}

As survivors, we work hard. We work hard so that we can prove to the perpetrators that they did not ruin us completely. Others did not expect us to survive or to go on and live good lives. So we work hard so that we can have a better life, so that we can thrive.

\section{The source of these skills}

What is the source of these skills, these strategies, this strength? Like a river, there are many different sources.

\section{Necessity}

For some of us, the reason why we live together is that we don't have anywhere else to go. If we did have somewhere else to go, some of us would have gone there.

\section{Rwandan culture}

We draw strength from our culture. There are traditions within Rwandan culture that train us to be tolerant and resilient and to value our relationships with others. These cultural practices encourage us to always move forwards, to look to the future. And these ways of thinking tend to bring people together. We draw on these aspects of our culture and they support us to live side by side. 


\section{Concern for our children}

For some of us, it is our concern for our children that gives us strength and makes it possible to start new relationships with the families that have done us harm. My children will grow up in this country. I don't want them to be isolated here and so I have taken the initiative to start participating in the lives of the other families. The source of some of our initiatives to make peace is our concern for our children. We are taking this journey for the new living.

\section{Government policy}

Our government promotes unity and reconciliation. It tries to introduce these notions at all different levels of life in the community. This policy contributes to our efforts, our skills and our strategies.

\section{Social interest}

Here in Rwanda, we are not autonomous individuals. People are interdependent. Our economic and social interests are joined. We need each other. This knowledge is one of the sources of our efforts to live side by side.

\section{Drawing inspiration from our loved ones}

We are survivors and we draw inspiration from our lost loved ones. We use their strength to move us forward and to better our lives. We use our parents as inspiration. We continue their dreams, their ambitions, and the projects that they had for their lives.

Our lost loved ones inspire us to live a good life. For when we are living a good life it is then possible to live side by side with pride. Every day, as we live in the shadow of genocide, we draw inspiration from our lost loved ones, and keep their legacies alive.

We are survivors and we are counsellors. These are our skills of living side by side in the shadow of genocide. We have also included the sources of our skills, our strategies, and our strength. Like a river our skills have many sources. We hope our words may be of assistance to others. 
The words in this document were also transformed into a song 'Vivre ensemble dans l'ambre du génocide' (Living side by side in the shadow of genocide) ${ }^{5}$ which was ritually performed and recorded. This song became a motif that was repeated at significant times during the week-long workshop.

The development and performance of such a document and song can serve many purposes. For instance, each time they are performed this enacts:

-An acknowledgement of the difficulty of the continuing circumstance of survivors;

-A recognition of the skills, knowledge and agency of survivors;

-A proclamation of preferred collective identity;

- An honouring of those who have been lost and the legacies that are being carried forth;

- A method of sharing knowledge between survivors;

- An invitation to other survivors to consider their own skills, knowledges that are implicit in how they are responding to 'living side by side'.

This entire process involved eliciting and richly describing particular local knowledge about 'living side by side'. This emphasis on local knowledge recognises the profoundly diverse concepts of living that individuals, groups, communities and cultures use in attempting to deal and come to terms with experiences of social harm. One aim of narrative

${ }^{5}$ The words of the document were skilfully transformed into song in French by Pierre Blanc-Sahnoun. The recording of the song features Pierre Claver Hodali Irakoze, Venant Tumukunde, Pierre BlancSahnoun and Aya Okumura. The song can be heard at: www.divshare.com\%2Fdownload\%2F13249090-823\&h=9b5de 
practices is to honour and sponsor such diversity. The phrase 'living side by side' had been offered by the Ibuka workers and so this was the theme around which the response was generated. Had the Ibuka counsellors initiated conversations that privileged alternative concepts such as those of 'reconciliation' or 'forgiveness' (which are common themes in other contexts), then the document created would have richly described these alternative concepts and the social histories of these. But these were not the concepts that were put forward. Instead, narrative practices were used to elicit and then richly describe the knowledge, values, skills and philosophies implicit within the phrase 'living side by side' ${ }^{6}$

We are now looking forward to sharing this document with others who are 'living side by side' with those who have done them harm. We are also interested in exploring how this sort of document could be shared and put to broader use within 'peace-building', 'justice', 'social healing' and/or 'reconciliation' projects within Rwanda and elsewhere.

\section{(iv) Exchanging local knowledge and enabling contribution}

Over the last six years, collective documents, songs and messages have been exchanged between Ibuka counsellors and Aboriginal Australian, Jewish and Native American colleagues (Denborough, Freedman and White, 2008). One of the most powerful exchanges took place in Cairns, when we played a DVD of the Ibuka document 'Living in the shadow of genocide: how we respond to hard times' to a group of Aboriginal and Torres Strait Islander counsellors who made up the 'Drop the Rock' team. Tileah Drahm-Butler sent the

${ }^{6}$ See Lederach (1995) in relation to the significance of elicitive approaches to peace-building in order to avoid cultural imposition. For rich discussions about diverse concepts of 'forgiveness', see Wiesenthal (1998). See also the special issue of the International Journal of Narrative Therapy and Community Work on 'The question of forgiveness' (2002, Issue no 1). 
following message back to Ibuka workers:

Hearing your words and stories about how you are going about reclaiming your lives and living with dignity makes me think of our ancestors. These are the sorts of things they would have been trying to do fifteen years on from the genocide that took place in this land. We would like to send to you our 'Drop the Rock song' in appreciation of your words and your work.

This song was embraced by the Ibuka counsellors ${ }^{7}$.

This sort of interchange involves an exchange of local insider-knowledge between groups of genocide survivors and their descendants (see Epston, 1999, 2001). Within these exchanges, all those who are participating experience being linked with and making contributions to the lives of others (Denborough, 2008). This experience of making contributions to the lives of other survivors can be powerfully significantparticularly when these contributions are consistent with carrying on legacies from one's ancestors.

On our most recent visit, Ibuka counsellors explicitly requested that our discussions consider a complex dilemma they are often dealing in their work:

During the Gacaca justice processes, some survivors had hoped that perpetrators who came forth and confessed their crimes would be able to tell us where they buried our loved

${ }^{7}$ As Jill Freedman (personal communication, 20 January 2011) describes: 'We brought a number of copies of the song on CDs. We played it and talked about it and Patrick Iregura translated the lyrics, and then the Ibuka counsellors wanted to hear it again. Although most of the Rwandan counsellors don't speak English, the next day at break, you could hear people singing "Drop the rock. Drop, drop the rock..." I think this song really brought home to the workers of Ibuka that these were real people from a different place who wanted to link with them'. 
ones. But some of us did not learn this and it has undermined the healing process. Now some survivors are continually asking and lamenting 'how can we find the remains of our loved ones? How can we bury them?' How can we assist these survivors who cannot find the bodies of their loved ones?

The Ibuka counsellors said they would be interested to hear from Jewish colleagues about how they have responded to similar situations. During this most recent meeting, a number of Jewish narrative practitioners were present. Prior to coming to Rwanda they had conducted their own research both personally in relation to their families, and professionally, about some of the ways in which Jewish survivors of the Holocaust had responded to 'the problems of memory'.

In response to the Ibuka counsellors request, these Jewish practitioners gathered together some of their 'local knowledge' on this issue of honouring those who have been killed when their bodies have never been found. Representing the Jewish colleagues who were present, the following knowledge was shared 8 :

Good morning. This is a very profound moment for us. We will do our best to respond to your question by sharing with you thoughts that have been gathered through a group effort. As you probably know, the majority of the six million Jews who were murdered in the Holocaust were burned and so no remains were left. In Jewish tradition, the taking care of dead ones and burying them is a profoundly sacred act. It is considered an act of genuine kindness as you have no intention of receiving back. Being unable to bury our loved ones is a devastating experience in Jewish culture. As a result, after the Holocaust, very many practices have developed in

8 The Jewish narrative practitioners present included Yishai Shalif, Yael Gershoni, Jill Freedman, Ruth Pluznick, Rachel Paran, and Tali Gogol-Ostrowsy. Yishai Shalif spoke on behalf of this group. 
response to this difficulty of not having the remains of our loved ones. I will share with you some of these responses.

Many Holocaust survivors place in their wills that when they die and are buried they want not only their name written on their grave, but also the names of their loved ones who have no graves. In Jewish graveyards you can see these inscriptions.

As there were whole villages and whole communities in which no one was left, in cemeteries there are also headstones which list the names of those communities-in order to commemorate whole villages from where there were no survivors.

Naming is also significant in Jewish tradition. In many ways names have become a way to commemorate those who died with no remains. Children who were born after the Holocaust have been named after family members whose remains were not found. Similarly, places of significance such as homes, universities, avenues of trees, and institutes have also been named after people and communities who died during the Holocaust.

In Israel there is a particular national day on which we remember the Holocaust. It starts with a ceremony in which six fires are lit in memory of the six million people who perished. Usually these fires are lit by survivors or their descendants.

In more religious circles, there are a range of religious practices that are conducted in memory of those ones who died. In Jewish tradition, a person who lost a loved one says a particular prayer for 12 months after the death. This prayer is called a Kaddish. Because so many within the Holocaust did not have anyone to say Kaddish for them, a particular Kaddish day is set aside for them. We fast during this day in the temples and we say laments and prayers during this day.

Another project involves a particular Jewish text that has six parts. These six parts act as a reminder of the six million who died in the Holocaust. Every day, thousands and thousands 
of Jews say parts of these prayers in remembrance of those who died.

There is another response that is highly significant. Many Jews who know they will never find the remains of their loved ones seek memories of them. To this day, 65 years since the Holocaust, there is a program on the radio in which people call up and ask listeners if anyone has particular memories of their lost loved ones.

Many people also undertake personal searches, they travel back to Europe trying to find remains of memories. Some people transform these memories into movies or books.

And just as you have here in Rwanda, there is also a project in the centre for commemoration to collect the names of those who died. Any person who knows someone who perished is asked to fill out a form with their information on it. So far they have collected three and a half million names and the process continues. On a personal note, whenever I go to this place and see the empty places set aside for those whose names have not yet been recorded I am very moved.

These are some of the ways that Jewish people have responded to the devastating experience of not being able to find the bodies of their loved ones.

A Hebrew prayer was then sung. The Ibuka counsellors spoke between themselves for a time before responding:

It was very moving to us to listen to the ways you are continuing to honour the victims of the Holocaust. It means a great deal to know that as a people, after many generations, you are able to keep the spirit of remembrance.

When you described the steps you are taking, I was reminded of all that we have been through here in Rwanda. I particularly related to the idea of having a place in the cemetery for the loved ones lost, a place of remembrance with their names and maybe a picture. I have made a personal commitment to do similarly, so that I too will be able to (visit) the cemetery and remember and feel more connected to those I have lost.

Your words reminded me of the many forms of commem- 
oration that we undertake here during the 100 days of memory each year. For instance, every year, in honour of those who were thrown into the rivers we go to the water for memory. There are so many ways in which we share memory during those 100 days.

Thank you for your words. It is important for survivors who are not able to bury their loved ones in dignity, to find other ways to honour them. I am going to share these stories with those with whom I am working. Please tell others in the Jewish community that they are our brothers and sisters. Please tell your people that.

Some of the Jewish participants were visibly moved by this exchange to the extent that the Ibuka counsellors offered comfort and tissues. A direct descendant of survivors of the Holocaust tried to articulate the significance of this exchange:

Something has changed for me today which is difficult to put into words. Until today, the Holocaust has always been a solely 'Jewish' experience. But being here with you, I feel joined in our mutual suffering and survival. One of the things that genocide tries to do is separate peoples and having the chance to feel that our experiences could be a contribution to you gives us renewed strength. At the same time, being welcomed by you in these ways, hearing from you about the ways in which you live in the shadow of genocide, and how you live side by side with those who have done you harm, has much to teach us. I am reminded by you that we are more than 'victims' to our experiences; we can also do great social good because of what we have learned from these experiences. In this way, the suffering of those who perished 'will not be for nothing'. Taking what we learned from their experiences and using it to make changes in our own communities and the world is a way to honour the lives and deaths and suffering of those we love.

At the end of this ritual, one of the Ibuka workers invited everyone to stand and to join in memories and honouring through song. 


\section{Reflections}

The words of Ibuka counsellors/survivors spoken 14 years after the genocide in Rwanda were so significant to Aboriginal Australian colleagues because it was as if these offered a glimpse as to how Aboriginal ancestors may have tried to deal with the genocide in Australia. And then the words of Jewish colleagues were so significant to Rwandan survivors because they demonstrate that 65 years after the Holocaust, future generations are continuing to honour and remember lost loved ones. These exchanges across time, across place, across culture involve the sharing of intimate local knowledge. This richly described knowledge honours the dead and the suffering, and contributes to the construction of sstories. These are stories of individual and collective identity that honour acts of resistance and sustenance, and that link these with the skills, values, commitments and philosophies of lost loved ones.

Over the last six years, Ibuka, Dulwich Centre Foundation International, and Evanston Family Therapy Center, have engaged with narrative therapy (White and Epston, 1990; Freedman and Combs, 1996; White, 2007) and collective narrative practice approaches (Denborough, 2008) in order to facilitate the excavation, documentation, performance and exchange of the local knowledge of Ibuka counsellors/ survivors.

This has included intricate insider knowledge in relation to:

- the continuing effects of the genocide,

- what sustains survivors as they live in the shadow of genocide,

- ways in which survivors negotiate 'living side by side' with those who have done them great harm, and

- ways of responding when survivors cannot locate the bodies of loved ones. 
This essay has detailed this knowledge and the narrative processes that have facilitated its visibility.

\section{Looking back, looking forwards}

We began this essay with the words Kaboyi Benoit greeted us with when we first visited Rwanda: 'Ah, Australia...there's a country that knows all about genocide'. Since that first meeting, six years ago, we have consistently retold Benoit's words in our work in Australia with both non-Aboriginal and Aboriginal colleagues. His words remind us to refuse to forget the genocide that occurred in this land, Australia, and to respond in partnership to its continuing effects.

It is hoped that there will be continuing possibilities to facilitate the linking and sharing of local knowledge between survivors of genocide and their descendants in Rwanda, Australia, in Jewish communities around the world, and elsewhere.

\section{Acknowledgements}

This chapter describes work developed from a partnership between Ibuka (a national organisation in Rwanda that represents survivor associations), Dulwich Centre Foundation International and Evanston Family Therapy Center. It has been written by David Denborough and Cheryl White (Dulwich Centre Foundation International) in collaboration with Hodali Irakoze Pierre Claver (Ibuka) and Jill Freedman and Gene Combs (Evanston Family Therapy Center). The following Ibuka counsellors have contributed to the content of this paper: Bonheur Albertine, Ingabire Agathe, Kabagambe Cyrille, Umubyeyi Reginne, Mwenzikazi Francoise, Murorunkwere Julienne, Habumuremyi Epaphre, Bakansanga Appolline, Nkima Claire, Karikwera Charlotte, Mukansoro Emmilienne, Kambibi Emilienne, Niyonsaba Asterie, Umulisa Clarisse, Twahirwa Laurent, Nyiramucyo Odette, Uwamwiza Jeannette, Dusabe Jessica, Kibukayire Olive, Rugwizangoga Yvonne, Mukarubayiza Beatrice, 
Harerimana Theophile, Umwiza Josephine, Vuguziga Paul Marie, Murebwayire Alice, Uwera Josette, Ukeye Josee, Musabyeyezu Sophie, Mukamana Adelite (The Co-ordinator of Counselors), Rutayisire Eugene, Munyaneza Francois, Dusabeyezu Alphonsine, Uwitonze Therese. Uwantege Jacqueline and Maggie Ziegler from the Kigali Genocide Memorial Center also participated at the most recent workshop referred to in this chapter. The following international colleagues have also been involved in the exchanges and meetings described here: Yishai Shalif, Ruth Pluznick, Yael Gershoni, Saviona Cramer, Barbara Wingard, Tileah Drahm-Butler, Rachel Paran, Tali Gogol-Ostrowsy, Kaethe Weingarten, Rick Maisel, Paul Browde, Jeff Zimmerman, Ron Schweitzer, Amaryll Perlesz, David Moltz, Eve Lipchik, Murray Nossel, Jonathan Morgan, Vanessa Jackson, Loree Stout, Angel Yuen, Gene Combs, Carolyn Koolmatrie, Norma Akamatsu, Manja Visschedijk, Jussey Verco, John Stillman, Anne Kathrine Løge, Pierre BlancSahnoun, Linda Moxley-Haggart, Carla Abrams, Yves Bree, Julie Epp, Don Gapp, Deborah Gill, Hilda Nanning, David Newman, Aya Okumura and Russ Whitewood. Patrick Iregura has played a critical translation role throughout all the work described here. The support of Forongo Janvier, Mukamana Adelite and Muanguha Freddy has also been significant.

\section{References}

Bellah, R M, Madsen, R, Sullivan, W M, Swidler, A, and Tipton, S M (1985), Habits of the Heart: Individualism and commitment in American life, Berkeley CA, University of California Press.

Denborough, D (2006), 'A framework for receiving and documenting testimonies of trauma', in Denborough, D (ed), Trauma: Narrative responses to traumatic experience, Adelaide, Australia: Dulwich Centre Publications, 115-31. (Reprinted from (2005), International Journal of Narrative Therapy and Community Work, [3 and 4], 34-42).

Denborough, D (2008), Collective Narrative Practice: Responding 
to individuals, groups, and communities who have experienced trauma, Adelaide, Dulwich Centre Publications.

Denborough, D (2010), Working with Memory in the Shadow of Genocide: The narrative practices of Ibuka trauma counsellors, Adelaide, Dulwich Centre Foundation International.

Denborough, D, Freedman, J, and White, C (2008), Strengthening resistance: The use of narrative practices in working with genocide survivors, Adelaide, Dulwich Centre Foundation.

Epston, D (1999), 'Co-research: The making of an alternative knowledge, in Narrative Therapy and Community Work: A conference collection, Adelaide, Dulwich Centre Publications, 137-57.

Epston, D (2001), 'Anthropology, archives, co-research and narrative therapy', in Denborough, D (ed), Family Therapy: Exploring the field's past, present and possible futures Adelaide, Australia, Dulwich Centre Publications, 177-82. Freedman, J, and Combs, G (1996), Narrative Therapy: The social construction of preferred realities, New York, W W Norton.

Kaboyi, B (2007), 'A small light as we walk this long road: The work of Ibuka', International Journal of Narrative Therapy and Community Work, (1), 47-50.

Lederach, J P (1995), Preparing for Peace: Conflict transformation across cultures, Syracuse NY, Syracuse University Press.

Nelson, L H (2001), Damaged Identities, Narrative Repair, Ithaca NY, Cornell University Press.

Turner, V (1969), The Ritual Process: Structure and antistructure, New York, Aldine de Gruyter.

Turner, V (1979), Process, Performance and Pilgrimage: A study in comparative symbology, New Delhi, Concept Publishing Company.

Wertsch, J V (2002), Voices of Collective Remembering, Cambridge, Cambridge University Press.

Westoby, P (2009), The Sociality of Refugee Healing: In dialogue with Southern Sudanese refugees resettling in Australia, Champaign IL, Common Ground. 
White, M (1997), Narratives of Therapists' Lives, Adelaide, Dulwich Centre Publications.

White, M (2004), 'Working with people who are suffering the consequences of multiple trauma: A narrative perspective', International Journal of Narrative Therapy and Community Work, (1), 45-76. Reprinted in Denborough, D (ed), (2006), Trauma: Narrative responses to traumatic experience, Adelaide, Dulwich Centre Publications, 25-85.

White, M (2007), Maps of Narrative Practice, New York NY, W W Norton.

White, M, Epston, D (1990), Narrative Means to Therapeutic Ends, New York, W W Norton.

Wiesenthal, S (1998), The Sunflower: On the possibilities and limits of forgiveness, New York, Schocken Books, Inc. 